\title{
THE
}

\section{Elevated atmospheric sulfur levels off the Peruvian coast}

\author{
E. S. Saltzman \\ D. L. Savoie \\ J. M. Prospero \\ R. G. Zika \\ B. Mosher \\ University of Rhode Island
}

Follow this and additional works at: https://digitalcommons.uri.edu/gsofacpubs

Terms of Use

All rights reserved under copyright.

\section{Citation/Publisher Attribution}

Saltzman, E. S., D. L. Savoie, J. M. Prospero, R. G. Zika, and B. Mosher (1986), Elevated atmospheric sulfur levels off the Peruvian coast, J. Geophys. Res., 91(D7), 7913-7918, doi: 10.1029/JD091iD07p07913.

Available at: http://dx.doi.org/10.1029/JD091iD07p07913

This Article is brought to you for free and open access by the Graduate School of Oceanography at DigitalCommons@URI. It has been accepted for inclusion in Graduate School of Oceanography Faculty Publications by an authorized administrator of DigitalCommons@URI. For more information, please contact digitalcommons-group@uri.edu. 
JOURNAL OF GEOPHYSICAL RESEARCH, VOL. 91, NO. D7, PAGES 7913-7918, JUNE 20, 1986

\section{ELEVATED ATMOSPHERIC SULFUR LEVELS OFF THE PERUVIAN COAST}

E. S. Saltzman, D. L. Savoie, J. M. Prospero, R. G. Zika

Rosenstiel School of Marine and Atmospheric Science, University of Miami

B. Mosher

Graduate School of Oceanography, University of Rhode Island

Abstract. Elevated levels of non-sea-salt sulfate and $\mathrm{SO}_{2}$ in samples collected of $\mathrm{f}$ the west coast of South America Indicate that there is a major source of atmospheric sulfur in the region of southern Peru and northern Chile. During a 1983 cruise, observed concentrations of non-sea-salt sulfur, $\mathrm{SO}_{2}$, selenium, arsenic, and antimony were comparable to levels reported for moderately polluted urban air. In contrast, methanesulfonic acid levels were typical of coastal marine alr. Clearly, the elevated atmospheric sulfur levels in this region cannot be ascribed to oceanic organosulfur emissions. The major inputs are tentatively attributed to the smelting of sulfide ores which is a major industry in this region. The transport of smelter derived aerosols to this region may have a number of consequences for the atmospheric and oceanic chemistry of the Peruvian upwelling area.

\section{Int roduction}

The relative importance of biogenic and anthropogenic sulfur emissions to regional and global atmospheric sulfur budgets is currently the subject of much interest and uncertainty. of particular interest are coastal regions, which are impacted by both marine and terrestrial air masses. The original motivation for this study was to investigate biogenic sulfur emissions from the highly productive Peruvian coastal upwelling areas and to assess their importance as precursors to non-sea-salt aerosol sulfate in that region. The results, however, suggest that the atmospheric chemistry of this area is dominated by anthropogenic rather than natural sources. In this report we present data from a cruise of the $R / V$ Researcher during 1983 and from cruises aboard the $R / V$ Matamoras, $R / V$ Unanue, and $\mathrm{R} / \mathrm{V}$ SNP-1 during 1979 (Figure 1) and briefly discuss some of the possible implications for the ocean/atmosphere chemistry of this region.

\section{Sampling and Analysis}

A11 aerosol samples for this study were collected on shipboard with wind direction sensors controlling the operation of the pumps; samples were collected only when the wind direction was within $90^{\circ}$ of the bow. Aboard the Matamoras, Unanue, and SNP-1 during 1979, bulk aerosol samples were collected by drawing air through $20 \times 25 \mathrm{~cm}$ Whatman 41 filters at a flow

Copyright 1986 by the American Geophysical Union.

Paper number 6D0181.

0148-0227/86/006D-0181\$02.00 rate of $1.2 \mathrm{~m}^{3} \mathrm{STP} / \mathrm{min}$, with nominal sampling periods of 1 day. During the 1983 Researcher cruise, cascade impactor samples were collected with a modified WeatherMeasure Corp. model 235 high volume cascade impactor, with slotted Whatman 41 filters as impactor surfaces. Assuming a particle density of $1.2 \mu \mathrm{g} / \mathrm{cm}^{3}$ (sea salt at $80 \%$ relative humldity), the $50 \%$ cutoff diameters for stages $1-6$ were $16.7,8.4,4.2,2.1$ and 0.5 microns, respectively. The impactor was backed by two $20 \times 25 \mathrm{~cm}$ Whatman 41 filters and a dry filter to collect particles less than 0.5 micron in diameter, followed by a $\mathrm{Na}_{2} \mathrm{CO}_{3}$-glycerol impregnated filter to collect $\mathrm{SO}_{2 \cdot 3}$ Individual air samples ranged from 370 to $1800 \mathrm{~m}_{3} \mathrm{STP}$, and were collected at a flow rate of $0.86 \mathrm{~m}^{3} \mathrm{STP} / \mathrm{min}$.

For analysis, the slotted Impactor filters and quarter sections of backup filters were extracted with $20 \mathrm{ml}$ of Milli-Q water (16 Mohm $\mathrm{cm}$ ). The extracts were filtered through prewashed 0.45 micron filters and stored at $5^{6} \mathrm{C}$ until analyzed. The extracts were analyzed for sodium by atomic absorption spectroscopy $(+2 \%)$ and for nitrate and sulfate by lon chromatography ( $+5 \%$ [Savoie and Prospero, 1982]). Selected cascade impactor samples were also analyzed for methanesulfonic ac1d (MSA) by ion chromatography [Saltzman et a1., 1983], and for selenium, arsenic, and antimony by instrumental neutron activation analysis.

\section{Results and Discussion}

The sampling locations and bulk concentrations of $\mathrm{SO}_{2}$, non-sea-salt (nss) sulfate, nitrate, and sodium during the four cruises are illustrated in Figure 1. Also included in that figure is the approximate track of a cruise by Maenhaut et al. [1983], who collected nine impactor samples en route from Panama to the Galapagos Islands between April 30 and May 16, 1979. All of the samples reported here were collected south of the intertropical convergence zone. With the exception of those obtained on the 1983 Researcher cruise, all samples in Figure 1 were collected during the first 6 months of 1979.

The lowest mean concentrations of nss sulfate were found north of the equator. The average concentration of ngs sulfate in the 11 Matamoras samples $\left(0.58 \mathrm{~g} / \mathrm{m}^{3}\right.$ STP; Flgure 1) is comparable to those which have been reported in many open ocean areas, including the central region of the equatorlal Pacific [Prospero et al., 1985]. For the cruise from Panama to the Galapagos Islands, Maenhaut et a1. [1983] reported a geometric meap fine-particle sulfur concentration of $0.12 \mathrm{~g} / \mathrm{m}^{3}$ STP (standard geometric deviation=1.21). Assuming that all of the fine-particle sulfur is present as sulfate and exhibits a lognormal 

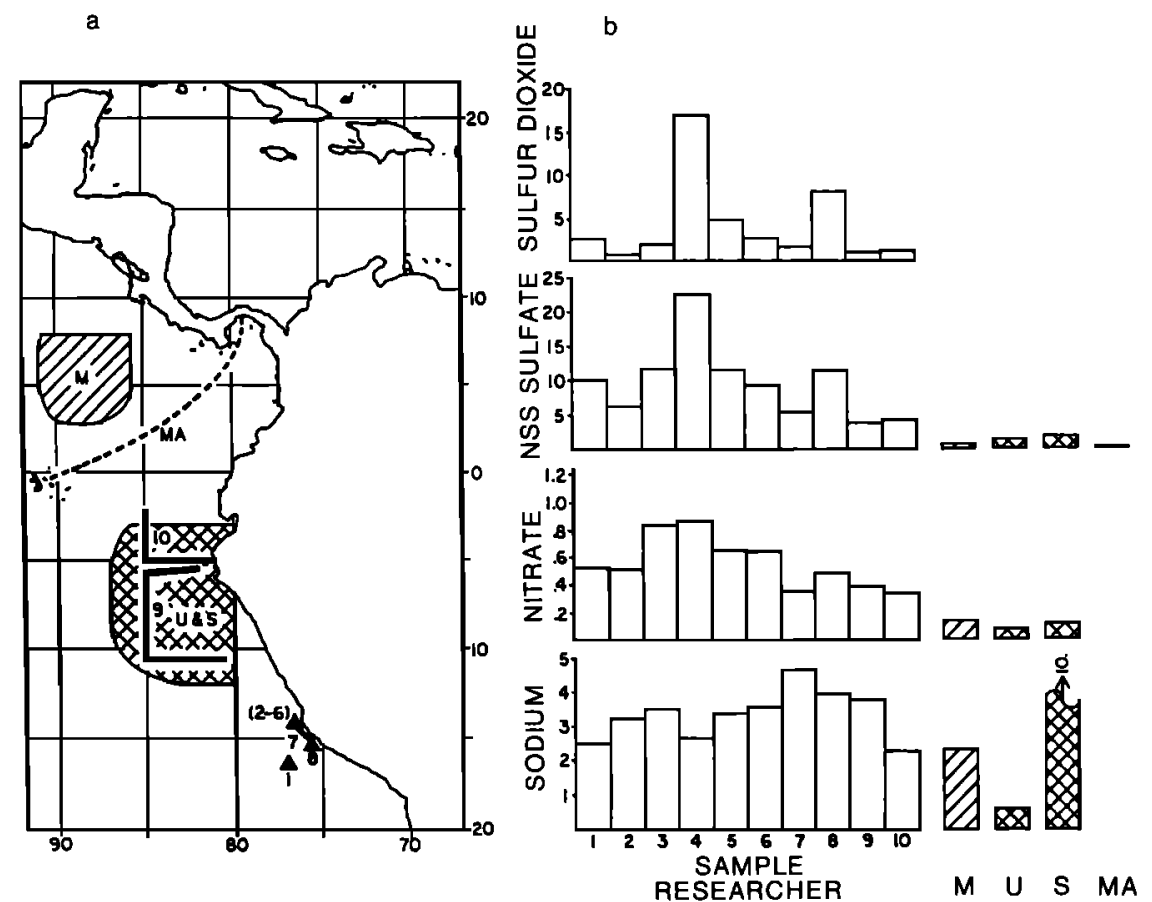

Fig. 1. (a) Map of the study area. (b) 3 Summary of nss sulfate and nitrate data from this region. Concentrations are in $\mu \mathrm{g} / \mathrm{m}^{3}$ STP. The following abbreviations are used: M, Maenhaut et al., [1983]; U, R/V Unanue; S, R/V SNP-1; Ma, R/V Matamoras. Sample locations from the 1983 Researcher cruise are numbered.

distribution, the mean fine particle sulfate concentration is $0.36 \mu \mathrm{g} / \mathrm{m}^{3}$ STP $(s=0.07)$. This concentration is about $40 \%$ lower than the mean from the Matamoras data. The difference might reflect a real temporal variability. Notably, the mean nss sulfate concentration in the Matampras samples collected during May $1979, .34$ $\mu \mathrm{g} / \mathrm{m} S T P$, is essentially identical to that reported by Maenhaut et al. [1983].

In the region of the west coasts of southern Ecuador and northern Peru, between $4^{\circ} \mathrm{S}$ and $12 \% \mathrm{~S}$, two sets of samples were collected during 1979. Nine samples were collected during the January-February cruise of the $R / V$ Unanue and 12 were collected during the May-June cruise of the $\mathrm{R} / \mathrm{V}$ SNP-1. The mean nitrate and nss sulfate concentrations on the two cruises were essentially the same. The nitrate concentrations in this region are similar in both mean and range to those found north of the equator. In contrast, the mean nss sulfate concentration near the Peru-Ecuador coast is nearly a factor of 3 greater than in the more northern area.

The $1983 \mathrm{R} / \mathrm{V}$ Researcher (NOAA R-103) cruise off the southern coast of Peru took place from June 29 to July 15, 1983 (Figure 1). This was a period of transition from $E 1$ Nino to normal upwelling conditions. The increased nitrate levels and lower surface temperatures observed at a coastal station during early July suggest that there was a rapid return to the nutrient rich conditions observed during normal years [Atwood et al., 1983]. The prevailing winds during the Researcher cruise were from the southeast at speeds of 10 to 20 knots ( 18 to $36 \mathrm{~km} / \mathrm{hr}$ ).

Results from the $1983 \mathrm{R} / \mathrm{V}$ Researcher cruise provide further evidence for the trend of increasing nss sulfate concentrations to the south. In the two samples collected off northern Peru, the mean concentration of nss sulfate was $4.0 \mathrm{\mu g} / \mathrm{m}^{3} \mathrm{STP}$. In comparison, the mean nss sulfate concentrafion off the coast of southern Peru was $11 \mu \mathrm{g} / \mathrm{m}^{3}$ STP, a factor of 2.7 higher. Similarly, the mean concentrations of nitrate and sulfur dioxide off southern Peru are greater by factors of 1.7 and 5 than those to the north. These sulfur dioxide levels are a factor of 15 greater than those reported by Bonsang [1980] for the Peru upwelling area. Also notable is the nss sulfate:nitrate ratio of 20 off southern Peru. In most regions of the marine boundary layer this ratio falls in a relatively narrow range between 1 and 3 [Savole, 1984].

Collectively, the above observations indicate that there is a major source of atmospheric sulfate (and nitrate, to a much lesser extent) in the region of southern Peru. In order to investigate the possible origin of these compounds, we analyzed two samples from the Researcher cruise for a number of water soluble trace constituents, including MSA, selenium, arsenic and antimony. These two samples were chosen because they contained high levels of both nss sulfate and sulfur dioxide. The total soluble concentrations of these species are shown in Table 1. Also included in Table 1 are concentration ranges previously reported from remote open ocean areas.

MSA is a product of the atmospheric oxidation of organosulfur compounds such as dimethylsulfide (DMS), methyl mercaptan, and dimethy1disulfide. Because of the relative constancy of the ratio of MSA to nss sulfate in remote marine areas, MSA has been proposed as a tracer for oceanic emissions of biogenic organosulfur compounds. The MSA levels of $f$ southern Peru fall 
TABLE 1. Comparison of Concentrations in Coastal Peru Aerosol Samples With the Marine Background

\begin{tabular}{|c|c|c|c|c|}
\hline & $\begin{array}{r}\mathrm{MSA}_{3} \mathrm{~g} / \mathrm{m} \\
\end{array}$ & $\begin{array}{c}\mathrm{Se} \\
\mathrm{ng} / \mathrm{m}^{3}\end{array}$ & $\begin{array}{c}\mathrm{As} \\
\mathrm{ng} / \mathrm{m}^{3}\end{array}$ & $\begin{array}{c}\mathrm{Sb} \\
\mathrm{ng} / \mathrm{m}^{3}\end{array}$ \\
\hline Sample 4 & 0.053 & 1.310 & 51.3 & 1.211 \\
\hline Sample 5 & 0.076 & 0.784 & 27.5 & 0.540 \\
\hline Marine background & $0.001-0.33$ & $.016-0.30$ & $0.01-0.21$ & $0.004-0.11$ \\
\hline
\end{tabular}

Background values are from Saltzman et al. $[1983 ; 1985 ; 1986]$ for MSA, Duce et a1. [1983] and Mosher and Duce [1983] for Se and Sb, and Walsh et al. [1979] for As.

within the range of values found at marine stations throughout the world. They are typical of areas of moderate to high productivity, such as the Pacific equatorial divergence zone and the Gulf of Mexico [Saltzman et al., 1983; 1985; 1986]. The MSA/nss sulfate ratios in Researcher samples 4,5 and 6 were $0.002,0.007$ and 0.006 , respectively, roughly an order of magnitude less than that at remote marine stations $(0.060+0.031)$. Figure 2 is a plot of MSA versus nss sulfate concentrations measured at marine stations. The ratios near Peru are clearly anomalous. Consequently, we conclude that the source of the elevated nss sulfate must be quite different in composition from normal oceanic emissions.

During the 1983 Researcher cruise, surface ocean DMS levels ranged from 0.13 to $4.2 \mathrm{nM}$ (mean 1.81 , standard deviation 1.13, $n=19$ ( $w$. Cooper et al., 1983, unpublished data)). These levels are comparable to those reported for oligotrophic areas [Andreae and Raemdonck, 1983]. These data, in agreement with the MSA data, suggest that DMS does not contribute significantly to the anomalously high levels of atmospheric sulfur observed during 1983. One year prior to this study, under normal upwelling conditions, Andreae and Raemdonck [1983] reported an average surface DMS concentration of $7.2 \mathrm{nM}$, with extremely high values in localized areas of high productivity. Although biogenic organosulfur emissions undoubtedly play an important role in maintaining background levels of nss sulfate and $\mathrm{SO}_{2}$ over the oceans; they could not be the source of the elevated sulfate and sulfur dioxide levels found in this study.

Selenium, arsenic, and antimony are commonly highly enriched in hydrothermal sulfide ore deposits and are incorporated into the aerosol during smelting [Ragaini et al., 1977; Small et a 1., 1981; Germani et a1., 1981]. Selenium levels in the Researcher samples from Peru are

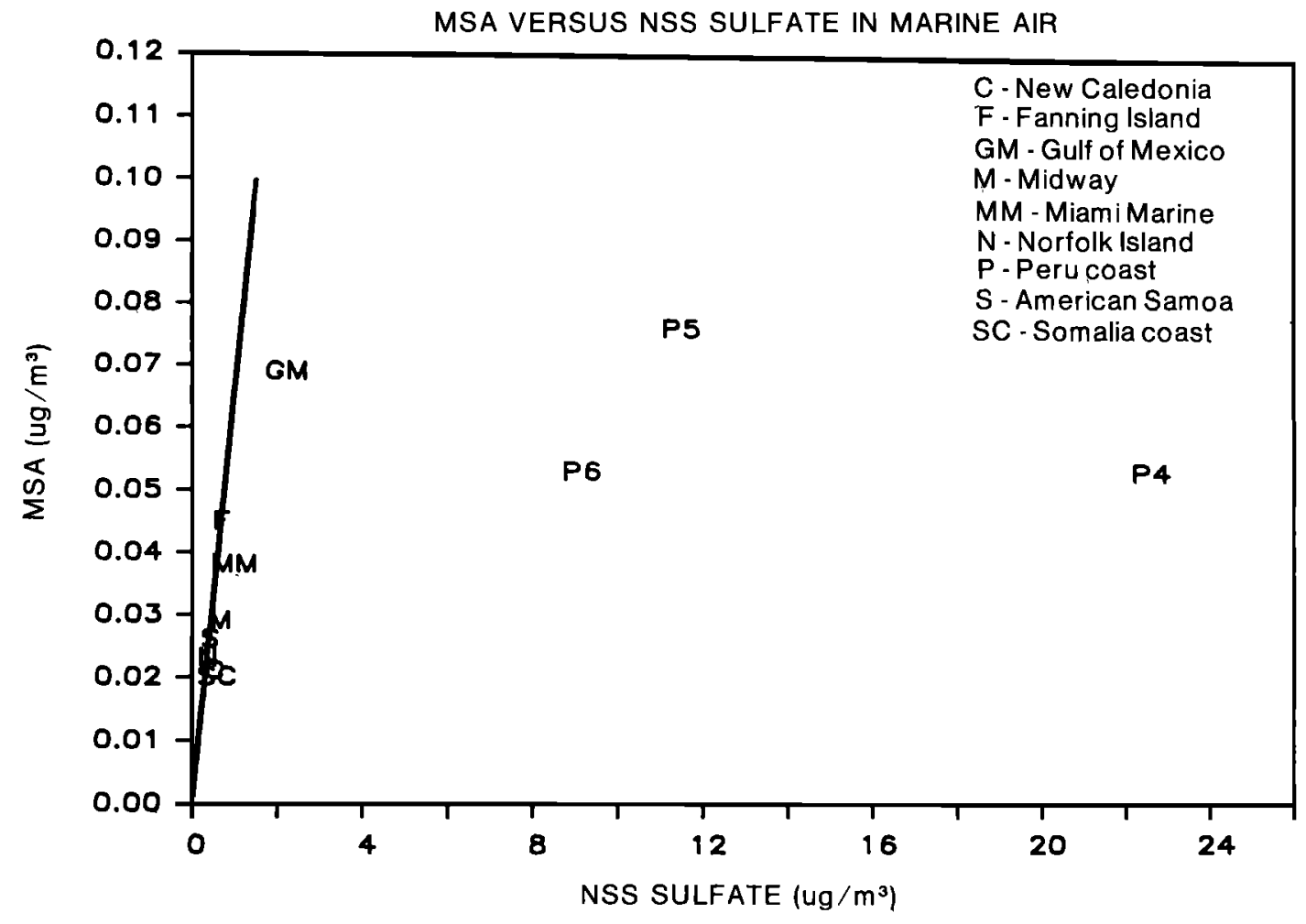

Fig. 2. Plot of MSA versus nss sulfate for remote marine stations [Saltzman et al., 1983; 1985; 1986] and samples from this study. 


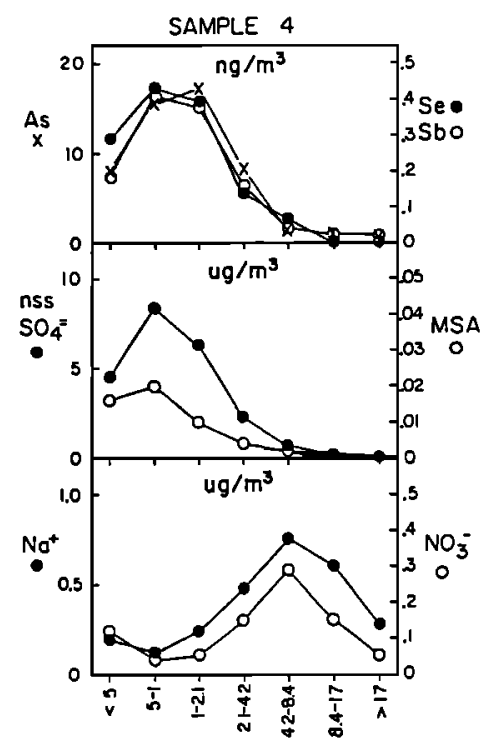

PARTICLE DIAMETER RANGE (microns)

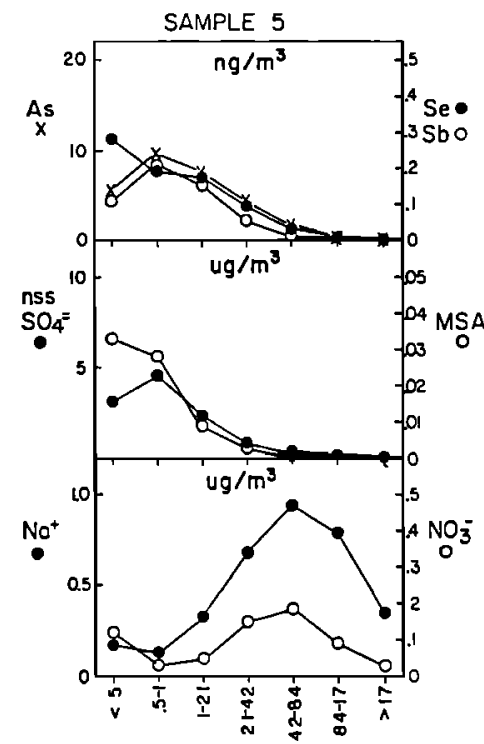

PARTICLE OIAMETER RANGE (microns)

Fig. 3. Chemical composition of aerosols collected off the coast of Peru as a function of particle size.

considerably elevated over those reported from remote marine air and are comparable to those from urban areas [Law et al., 1978]. Similar results were reported from samples collected in 1981 [Mosher and Duce, 1983], when particulate selenium concentrations of 0.64 and $0.51 \mathrm{ng} / \mathrm{m}^{3}$ were measured at $15^{\circ} \mathrm{S}, 75^{\circ} \mathrm{W}$. The samples analyzed in this study were also highly enriched in arsenic and antimony. The enrichment in arsenic is particularly notable; such high levels are typical of heavily industrialized areas [Walsh et al., 1979].

The composition of samples 4 and 5 from the 1983 Researcher cruise is shown as a function of particle size range in Figure 3. Sodium and nitrate exhibit similar size distributions and are concentrated primarily in the coarser particles. In contrast, the nss sulfate and MSA are found mainly on fine particles, with mass median diameters of less than 0.5 micron. These distributions are typical of marine aerosols and reflect the mode of incorporation of the various species into the aerosol: sodium via sea spray; nitrate via heterogeneous scavenging of gas phase nitric acid by sea salt aerosols; and the sulfur compounds via homogeneous oxidation of gaseous precursors followed by hydration, nucleation, and coalescence. Selenium, arsenic, and antimony, 1 ike nss sulfate, are concentrated in particles of less than l micron in diameter. The size distribution of selenium in these samples differs markedly from that found at Enewetak [Duce et a1., 1983]. At that station most of the selenium is associated with Asian dust [Yang et al., 1981] and, consequently, was present in particles of 1 to 3 microns in diameter. Of $\mathrm{f}$ Peru these elements probably originate from volatilization during sulfide ore smelting, a process which results in condensation of vapor phase selenium on fine particles [Smith et al., 1979; Natusch et a1., 1974].

The above evidence suggests that the extremely high levels of atmospheric sulfur observed off Peru during the 1983 cruise are the result of anthropogenic activity; probably the smelting of copper sulfide ore in northern Chile. Because the biological activity of the Peru shelf can be extremely high at times, biogenic sources must also be considered. However, MSA concentrations suggest that organosulfur emissions from the surface ocean were not anomalously high. Another possible source of biogenic sulfur in this region is $H_{2} \mathrm{~S}$. During previous El Nino years, the cessation of upwelling has resulted in the development of anoxia in the surface ocean. Under these conditions, rapid production of $\mathrm{H}_{2} \mathrm{~S}$ and ammonia may occur via sulfate and nitrate reduction. While no attempt was made to measure ambient $\mathrm{H}_{2} \mathrm{~S}$ levels during the 1983 Researcher cruise, its odor was never present in the air and anoxic conditions were not observed in the water column. It is difficult to rule out significant $\mathrm{H}_{2} \mathrm{~S}$ emissions entirely; because of the patchy nature of ocean1c productivity, anoxic conditions may have been present but not sampled during the cruise. However, enrichment of the aerosol in heavy elements such as copper (B. Mosher, 1983 unpublished data) and antimony argues against an oceanic origin for the sulfur.

\section{Conclusions}

The Peru shelf has been extensively studied by oceanographers as a model for physical, chemical, and biological coastal upwelling processes. As a result of the growing interest in air/sea exchange this region has also become the focus of numerous studies of biogenic oceanic emissions. The results of this study urge caution in the interpretation of atmospheric concentration measurements of oceanic emissions on the Peru shelf for two reasons. First, the smelter emissions may be a source of the compound of interest. For example, atmospheric measurements 
of $\mathrm{SO}_{2}$ and nss sulfate in this area have been used as evidence for a regional correlation between oceanic productivity and emissions of reduced sulfur compounds [Bonsang, 1980]. While such a relationship may certainly exist elsewhere, it is suspect in this region.

A second factor to consider is that the impact of smelter emissions on the lower tropospheric chemistry of this region may affect the lifetime of reactive species in air. These impacts might include: high $\mathrm{NO}_{\mathrm{X}}$ levels leading to increased $\mathrm{O}_{3}$ and $\mathrm{NO}_{3}$ production, increased levels of gaseous HC1 and $\mathrm{HNO}_{3}$ due to coalesence of sea salt aerosols with highly acidic sulfuric acid aerosols, and enhanced catalysis and/or inhibition of thermal and photochemical heterogeneous reactions due to the abundance of metals in the aeroso1. Consequently, both the reaction rates and reaction pathways of many species off Peru may be markedly different from those in the remote marine troposphere.

The transport of smelter derived aerosols to coastal areas off Peru may also have consequences for the marine chemistry of this region due to the increased deposition of trace metals to the sea surface. Hydrothermal sulfide deposits associated with subduction zones, like that in Chile, are enriched in a variety of metals, including $\mathrm{As}, \mathrm{Sb}, \mathrm{Au}, \mathrm{Ag}, \mathrm{Hg}, \mathrm{Tl}, \mathrm{Cu}, \mathrm{Pb}, \mathrm{Zn}, \mathrm{Mn}$, and $F e$ [Weissberg et al., 1979]. The flux of these metals via aerosols to the sea surface oft Peru is certainly much greater than that normally found in remote coastal regions, and this may be reflected in the depth profiles and speciation of some elements.

In conclusion, the results of this study suggest that atmospheric sulfur levels off Peru are dominated by anthropogenic, rather than biological, sources. Because of the limited nature of the data set we cannot assess spatial or temporal variability of this input, or the magnitude of its effects. It is clear, however, that from an atmospheric and oceanographic point of view this region should not be viewed as pristine; the smelter input may significantly modify the distribution of many redox active species in the lower atmosphere and, possibly, the surface ocean.

Acknowledgements. The authors wish to thank NOAA/AOML for the opportunity to participate in the 1983 Researcher cruise. This research was supported by NOAA grants NA82RAC00096 and NAB2RAC0052, and by NSF grants ATM-8405921, ATM-8209759, and ATM-8016127.

\section{References}

Andreae, M. O. and H. Raemdonck, Dimethylsulfide in the surface ocean and the marine atmosphere: A global view, Science, 221, 744-747, 1983.

Atwood D.K., S. R. Piotrowicz, and G. A. Berberian, Rapid response of coastal waters of southern Peru at $150 \mathrm{~S}$ to relaxation of the 1982/1983 E1 Niño, Trop. Ocean Atmos. Newslett., 21, 29-30, 1983 .

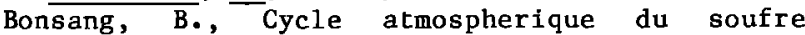
d'origine marine, these d'etat, Univ. de Picardie, St. Quentin, France, 1980.

Duce, R. A., R. Arimoto, B. J. Ray, C. K. Unni, and P. J. Harder, Atmospheric trace elements at Enewetak Atoll, 1, Concentrations, sources, and temporal variability, J. Geophys. Res. $88,5321-5342,1983$.

Germani, M. S., M. Small, W. H. Zoller, and J. L. Moyers, Fractionation of elements during copper smelting, Environ. Sci. Technol., 15, 299-305, 1981 .

Law, D. V, C. Healy, D. H. F. Atkins, L. Salmon, and E. M. R. Fisher, Retrospective trend analysis of the content of U.K. air particulate material 1957-1974, Sci. Total Environ., 9, 161, 1978.

Maenhaut, W., H. Raemdonck, A. Selen, R. Van Grieken, and J. W. Winchester, Characterization of the atmospheric aerosol over the eastern equatorial Pacific, J. Geophys. Res., 88, 5353-5364, 1983.

Mosher, B. W. and R. A. Duce, Vapor phase and particulate selenium in the marine atmosphere, J. Geophys. Res., 88, 6761-6768, 1983.

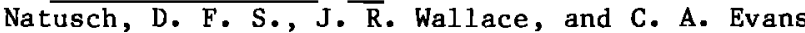
Jr., Toxic trace elements: Preferential enrichment in respirable particles, Science, 183, 202-204, 1974 .

Prospero, J. M., D. L. Savoie, and R. T. Nees, Particulate sulfate and nitrate in the boundary layer over the North Pacific ocean, J. Geophys. Res., 90, 10,586-10,596, 1985.

Ragaini, R. C., H. R. Ralston, and N. Roberts, Environmental trace metal contamination in Kellogg, Idaho near a lead smelting complex, Environ. Sci. Technol., 11, 773-781, 1977.

Saltzman, E. S., D. L. Savoie, R. G. Zika, and J. M. Prospero, Methane sulphonic acid in the marine atmosphere, J. Geophys. Res., 88, 10897-10902, 1983.

Saltzman, E. S., D. L. Savoie, J. M. Prospero, and R. G. Zika, Atmospheric methanesulfonic acid and non-sea-salt sulfate at Fanning and American Samoa, Geophys. Res. Lett., 12, $437-440,1985$.

Saltzman, E. S., D. L. Savoie, J. M. Prospero, and R. G. Zika, Methanesulfonic acid and non-sea-salt in Pacific air: regional and seasonal variations, Atmos. Chem., in press, 1986.

Savoie, D. L., Nitrate and non-sea-salt sulfate over major regions of the world ocean: concentrations, sources, and fluxes, thesis, Univ. of Miami, Miami, Fla., 1984.

Savole, D. L. and J. M. Prospero, Particle size distribution of nitrate and sulfate in the marine atmosphere, Geophys. Res. Lett., 9, $1207-1210,1982$.

Smal1, M., M. S. Germani, W. H. Zoller, and J. L. Moyers, Airborne plume study of emissions from the processing of copper ores in southeastern Arizona, Environ. Sci. Technol., 15, 293-299, 1981 .

Smith, R. D., J. A. Campbe11, and K. K. Nielson, Concentration dependence upon particle size of volatilized elements in fly ash, Environ. Sci. Techno1., 13, 553-558, 1979.

Walsh, P. R., R. A. Duce, and J. L. Fasching, Tropospheric arsenic over marine and continental regions, J. Geophys. Res., 84, $1710-1718,1979$.

Weissberg, B. G., P. R. L. Browne, and T. M. Seward, Ore metals in active geothermal systems, in Geochemistry of Hydrotherma1 Ore 
Deposits, edited by H. L. Barnes, pp 738-780, John Wiley, New York, 1979.

Yang, S. J., Q. F. Quian, M. Y. Zhou, S. H. Qu, Q. M. Song, and Y. Y. Li, Some properties of the aerosols during the passage of a dust storm over Beijing, China, April 17-20, 1980, Spec. Pap. Geol. Soc. Am., 186, 159-167, 1981.

J. M. Prospero, E. S. Saltzman, D. L. Savole, and R. G. Zika, Rosenstiel School of Marine and
Atmospherlc Science, University of Miami, Rickenbacker Causeway, Miami, FL 33149.

B. Mosher, Center for Atmospheric Chemistry Studies, Graduate School of Oceanography, University of Rhode Island, Narragansett, RI 02882 .

(Recieved January 14, 1986;

revised March 25, 1986;

accepted March 25, 1986) 